EWARYST KOWALCZYK IWONA LUBIMOW -BURZYŃSKA

\title{
Problem of Guidelines as \\ a Source of the Internal Law (on the Example of the Legislative \\ Practices in the Area of Management Control in the Educational Units, part II)
}

Ewaryst Kowalczyk, Ph.D. Iwona Lubimow-Burzyńska, Ph.D.

University of Zielona Gora Division of Macroeconomics and Finance

\section{Introduction}

In the first part there was presented an analysis of the legislation activity in a form of a simultaneous creation of the generally binding norms and internal guidelines in the area of the public finances, or more specifically, of the management control institution in the units of the public finances. Based on the regulations binding since 1 January 2010 included in the act on public finances from 2009 (J. of L. of 2009 No. 157, position 1240) (hereinafter referred to as p.f.a.) there was discussed a problem of using the guidelines as internal acts on the example of the legislative practice in the range of management control.

The aim of this presentation is the analysis of the issue of guidelines of the Minister of Finance on the standards of the management control for the public finances sector as well as the guidelines of the Minister of Finance in the range of self-assessment

Problem of Guidelines as a Source of the Internal Law (on the Example of the Legislative Practices in the Area of Management Control in the Educational 


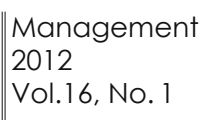

of the management control for the public finances units, especially taking into consideration educational units.

\section{Guidelines of the Minister of Finance on the Standards of the Management Control for the Public Finances Sector}

Pursuant to art. 69 of the act on public finances, ensuring adequate, efficient and effective management control is included in the duties of:

1. The minister in the departments of government administration managed by him, hereinafter referred to as the "minister managing a department", subject to section 2 .

2. Wójt /head of the commune/, mayor, chairman of the management board of the local government unit.

3. Head of the unit.

The records of the p.f.a. are directly connected with functioning of the management control system on two levels:

1. Financial control system in government administration department (level 2 of the management control),

2. Management control system in individual units (level 1 of the management control).

The aim of the management control is ensuring especially:

1. Conformity of the activity with the legal regulations and internal procedures.

2. Activity efficiency and effectiveness.

3. Reports reliability.

4. Resources protection.

5. Observing and promoting the rules of ethical behaviour.

6. Effectiveness and efficiency of the information flow.

7. Risk management. (art. 68 section 2).

Management control covers all aspects of the unit's activity. The basic element of the management control is a responsibility of each head of the unit for the introduction and monitoring management control elements which enable the unit to reach set goals in a legal, effective, economic and punctual way.

Statutory delegation serving describing by Minister of Finance in a form of an announcement the management control standards for the public finances in conformity with international standards is to be found in art. 69 section 3 of the p.f.a. The Minister published the Announcement on the management control standards for the public finances sector on 16 December, 2009 (J. of L. 
MF No. 15, position 84). The standards provide two levels of the management control: on the level of a given unit of the public finance sector - level 1(i.e. schools and educational units) and on the level of the appropriate local government unit and a minister managing the given administration department - level 2. On the level of schools and educational units, the headmaster is responsible for the management control. The headmaster is obliged to ensure in a form of a statement information on the conditions of the management control for the previous year. Despite the fact that the p.f.o. does not mention it, it could be advisable for the headmaster of a school or educational unit to prepare a management control regulations.

Announcement No. 23 of the Minister of Finance was directed to the sector of public finance. Its content suggests that the addressees of the guidelines included in it are both minister and other heads of the organizational units within the frameworks of the government administration departments, and the heads of local government units and other units of the public finances sector. The Minister states in the Announcement that within the government and local government administration there should be functioning the management control appropriately on the level of government administration department, and also local government unit (so called management control level 2). A minister managing a given government administration department and wójt (mayor), governor or voivodship marshal, in case of the local government, are responsible for the functioning of the management control on this level. A minister is responsible for ensuring an adequate, efficient and effective management control system in the ministry (as a head of the unit) and in the government administration department (as a minister heading a department). Wójt (mayor), governor and voivodship marshal are responsible for ensuring adequate, efficient and effective management control system in a borough office (town office), poviat starosty or marshal's office as well as in a local government unit.

According to the wording of the Announcement, the management control standards for the public finances sector describe basic requirements concerning management control systems in the public finance units and they make a set of guidelines which unit heads should use to create, assess and improve management control systems in the units managed by them. The aim of standards is promoting introducing in the units a coherent and uniform control model compatible with modern standards and internal control model, including specific tasks which are completed by a given unit and conditions in which it works.

\footnotetext{
Problem of Guidelines as a Source

of the Internal Law (on the Example

of the Legislative Practices in the Area

of Management Control in the Educational

Units, part II)
} 


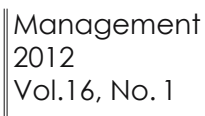

The content of the Announcement confirms a non-binding character of the guidelines included there. The management control standards formulated by the Minister of Finance are only a type of guidelines, which are formally non-binding acts, including an interpretation of regulations, recommendations and advice. Hence the guidelines cannot be a legal basis of judicial decisions, or even the control ones. However, they are the source of recommendations and advice which can be formed in the control process.

At the same time, pursuant to the amendment to the act of 17 December, 2004 on responsibility for the public finances discipline violation (J. of L. of 2005 No. 14, position 1114 as amended), failure or incorrect realization of the duties in the range of management control is covered by the responsibility for the violation of the public finances. The following records are examples:

- allowing a decrease in the incomes due to the State Treasury, local government unit or another unit of public finances as a result of negligence or failure to meet the duties in the range of management control (art. 5 section 2),

- allowing a spending causing exceeding the amount of expenditures set in an annual financial plan of the unit as a result of negligence or failure to meet the duties in the range of management control (art. 11 section 2),

- allowing the failure in completing unit's liabilities whose due date expired as a result of negligence or failure to meet the duties in the range of management control (art. 16 section 2),

- allowing the violation of the public finances discipline, connected with procurement, as a result of negligence or failure to meet the duties in the range of management control (art. 17 section 7),

- allowing by the head of the unit of the public finances sector violation of the public finances discipline connected with providing building works or services concessions, as a result negligence or failure to meet the duties in the range of management control (art. 17a section 5).

The management control standards - in accordance with the declaration of the Minister of Finance - were prepared based on generally acceptable internal management control included mainly in the documents entitled, "Internal control - integrated frame concept" and "Risk management in enterprises" - reports prepared by the Committee of Sponsoring Organizations of the Treadway Commission - COSO, "Guidelines on public sector internal control standards" - approved in 2004 by International Organization of Supreme Audit Institutions - INTOSAI and "The Revised Internal Control Standard for Effective Management" SEC (2007) 1341 appendix 1.

Issuing Announcement No. 23 of 16 December 2009, the Minister of Finance,

243

EWARYST KOWALCZYK

IWONA LUBIMOW-BURZYŃSKA 
in an ordered and logical way, described the above mentioned management control standards for the public finances sector. Those standards were ordered in five content-related areas:

- internal environment - described by 4 standards,

- goals and risk management - described by 5 standards,

- control mechanisms - described by 6 standards,

- information and communication - described by 3 standards,monitoring and assessment - described by 4 standards (internal audit does not concern school on level 1).

Within the standards, the general conditions of the unit, i.e. internal environment, are ascribed the main role in the management control system. As the Announcement describes, appropriate internal environment influences the management control quality in a fundamental way. Hence, appropriate environment is the foundation for other elements of the management control. The standards in this area concern unit management system and unit organization as a whole. They consist of such elements as:

- observing ethical values,

- employees' professional competence,

- unit's structural organization - it should be adjusted to the current goals and tasks,

- rights delegating - precisely described range of rights delegated to the specific employees.

Taking into consideration the management control definition, as found in art. 68 section 1 of the p.f.a., the system of determining goals and tasks for a unit, as well as the system of monitoring the determined goals and tasks, are the most vital elements of the management control.

A significant aspect of the management control is also the practice of risk management. Reaching goals in every unit - as the content of the Announcement states - is connected with the risk. Risk management is to serve increasing the possibility of reaching those goals. Hence, risk management is a control process timing at future, in which preventive function is realized in a specific way. Introducing the elements of risk management into the notion of the management control (previously, financial control) is an expression of the changes which the management control institution undergoes itself, i.e. the control realized within the unit (i.e. external), by people managing the units (i.e. functional). Hence, control in the management understanding is a set of actions which allow forming not only conclusions concerning existing events, but also recommendations necessary to design future events. Risk management corresponds with a catch-

Problem of Guidelines as a Source

of the Internal Law (on the Example

of the Legislative Practices in the Area

of Management Control in the Educational

Units, part II) 


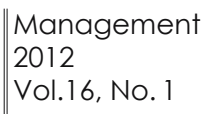

phrase presently popular in control - Manage before aMistake. (B. R. Kuc 2009, p. 9)

Risk management is also an element of the management control in educational units. However, taking into consideration a specific character of an educational unit, it is worth noticing that it is a local government budget unit without a legal personality, but with an approved financial plan. Such a legal status of the unit gives it specific legal conditions for work, which significantly limit its ability to take up risky activities on a high level. Risk level, which is acceptable to the governing body in the area of school management and administration, is set on the level which can be accepted by the body and which is justified.

The Minister of Finance's Announcement also constructs and exemplary list of the management control mechanisms, i.e. instruments (activities, actions, acts and decisions) constituting the management control process. The following are mentioned among them:

1. Documentation of the management control system - here we can also find an exemplary catalogue of documents which may be used in the process of control. Those may include internal procedures, instructions, guidelines, documents describing the range of employees' duties, rights and responsibility, as well as others, not mentioned internal documents which make up the documentation of the management control system,

2. Supervision of conducting the tasks in order to complete them in an economical, effective and efficient way,

3. Ensuring the existence of mechanisms serving keeping continuity of work of the public finances sector unit by using, among others, risk analysis results,

4. Unit's resources protection in a way that the access to them is limited to authorized people,

5. Detailed mechanisms of control concerning financial and economic operations as well as control mechanisms concerning IT systems.

The standards in the area of information and communication concern ensuring that all employees of the unit have access to the information necessary to do their duties, especially connected with the management control. The standard predicts that managing personnel and employees should have ensured access to the information necessary for them to complete their duties. The communication system shall make necessary information flow in the unit possible, in horizontal and vertical directions. An effective communication system should ensure not only the information flow, but also its appropriate understanding by the receiver. 


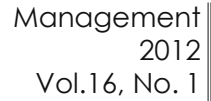

The standards in the range of monitoring and assessment introduce the rule of the constant assessment of the management control system functioning in a unit. The head of the unit is responsible for the assessment. Also, other people in the management positions may be obliged to conduct the current assessment of the management control functioning. Problems identified within the monitoring and assessment should be solved without delays. The assessment of the management control system can be done in a form of separate assessments conducted by the unit's employees (self-assessment). Self-assessment should be included in the frame of a process separate from the current activity, and should be documented.

\section{Guidelines of the Minister of Finance in the Range of Self-assessment of the Management Control for the Units of the Public Finances Sector}

On 16 February, 2011 the Minister of Finance published Announcement No. 3 on detailed guidelines on the self-assessment of the management control for the units of the public finances sector. Statutory delegation to the guidelines issued by the minister of Finance is to be found in art. 69 section 4 of the p.f.a., which states that the Minister of Finance may describe in the form of an announcement and publish, in the Official Journal of the Minister of Finance, detailed guidelines in the range of management control for the public finances sector.

In the Announcement, the Minister of Finance stated that one of the conditions of ensuring adequate, efficient and effective management control is its monitoring and functioning assessment, which may be conducted - among others - in a form of self-assessment of the management controlled encouraged in the Management control standards for the public finances sector included in Announcement No. 23, as mentioned above.

The Minister additionally explains that the Guidelines were prepared based on other guidelines, including management control standards for the public finances sector (Announcement No. 23 of the Minister of Finance of 16 December, 2009.), Guidelines for Internal Control Standards for the Public Sector; INTOSAI, Corporate risk management - integrated frame structure; The Committee of Sponsoring Organizations of the Treadway Commission, PIKW, 2007, Internal Control Management and Evaluation Tool; United States General Accounting Office and Revision of the internal control standards and underlying framework - strengthening control effectiveness; Communication to the Commission, Brussels, 16 October 2007, SEC(2007)1341.

The guidelines present the possible process of self-assessment using

Problem of Guidelines as a Source

of the Internal Law (on the Example

of the Legislative Practices in the Area

of Management Control in the Educational

Units, part II) 


$$
\begin{aligned}
& \text { Management } \\
& 2012 \\
& \text { Vol.16, No. } 1
\end{aligned}
$$

questionnaires and they include exemplary questionnaires which may be used by the units in the process. In the Announcement, the Minister also describes the role of the internal audit in the units of the public finances sector in the range of monitoring and management control assessment. The Minister reminds that the basic task of the internal auditor is providing the head of the unit with the independent assessment of the functioning of the management control in the unit. The share of the internal auditor in the process of self-assessment cannot influence the realization their basic tasks, their objectivism or independence.

Announcement No. 3 was directed at all the units of the public finances sector. In the justification to the Project of the Announcement it was stated that because the management control covers the activity of the whole unit, and its basic goal is ensuring the realization of goals and tasks, there appears the need of issuing the guidelines concerning the self-assessment of the management control for the units of the public finances sector in order to make it possible for the units to prepare to the process, conduct and document it, and - most of all - effectively use it as a tool of management control functioning assessment and a continuous improvement of the unit's functioning.

The control standards recommend conducting the self-assessment of the management control system at least once a year, to be conducted by the managing personnel and employees. Self-assessment should be included in the framework of the process separate from current activity, and it should be documented. Within the control assessment framework, it is also necessary receive the assurance of the management control condition. Its source for the head of the unit should be especially the results of monitoring, self-assessment and conducted audits and controls. The standards recommend annual confirmation of the reception of the above mentioned assurances in a form of a statement on the management control condition for the previous year.

\section{Conclusions}

In the legislative practice concerning public finances, the guidelines are more and more widely used. An example of using the guidelines are the Announcements of the minister of Finance on the management control in the public finances sector. However, using the guidelines in legislative practice goes beyond the doctrinal understanding of these sources of law, as their addressees are sometimes units which in organizational sense are not under the jurisdiction of the bodies issuing the acts. The examples of such guidelines are the Announcements of the Minister of Finance on the management control 


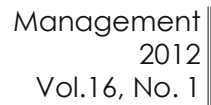

in the public finances sector as they were aimed at the units of the public finances sector which organizationally are not supervised by the Minister of Finance, e.g. educational units, which organizationally are supervised by the units of the local government.

For the educational units, the guidelines of the Minister of Finance are the directions for forming conclusions in the control process. In Announcement No. 23 there were published standards for five areas of the management control. It definitely makes management control in the unit easier for the people responsible for it.

New regulations do not enforce the necessity of a total change of the regulations formerly functioning in the educational unit, as the internal control or financial control are parts of the management control. However, the present set of the internal procedures needs to be updated and adjusted to new regulations. If necessary, it should be widend.

\section{Summary}

Problem of Guidelines as a Source of the Internal Law (on the Example of the Legislative Practices in the Area of Management Control in the Educational Units, part II)

The article is written on the guidelines of the Minister of Finance on management control in the units of the public finances sector, especially concerning educational units. The analysis covers the guidelines concerning management control standards and management control self-assessment. The work discusses the influence of the recommendations resulting from the announcements on the management control process in the educational units.

\section{Streszczenie}

Problem wytycznych jako źródła prawa wewnętrznego (na przykładzie praktyki legislacyjnej w zakresie kontroli zarządczej w jednostkach oświatowych cz. II)

Artykuł dotyczy wytycznych Ministra Finansów w sprawie kontroli zarządczej $\mathrm{w}$ jednostkach sektora finansów publicznych ze szczególnym uwzględnieniem jednostek oświatowych. Analizie poddano wytyczne dotyczące standardów kontroli zarządczej oraz samooceny kontroli zarządczej. Omówiono wpływ zaleceń wnikających z komunikatów na przebieg procesu kontroli zarządczej w jednostkach oświatowych. 


\section{References}

1. Anczakowski M. (2003), Audyt wewnętrzny w systemie kontroli wewnętrznej, „Kontrola Państwowa” nr 6.

2. Chojna-Duch A. (2004) Audyt wewnętrzny po akcesji do Unii Europejskiej, "Kontrola Państwowa" nr 4.

3. Gołębiowski G. (2003) Audyt wewnętrzny w administracji publicznej kontrowersje wobec jego roli, „Kontrola Państwowa” nr 6.

4. Jagielski J. (2003), Audyt wewnętrzny - miejsce w systemie kontroli i organizacji, „Kontrola Państwowa” nr 3.

5. Kałużny S., (2002) Leksykon kontroli, Desko, Warszawa.

6. Krysiak A.S. (2006), Pojęcie controllingu na tle pojęć zbliżonych (kontrola, audyt), „Kontrola Państwowa” nr 1.

7. Kuc B.R., (2009) Kontrola jako funkcja zarządzania, Difin, Warszawa.

8. Mik C, (2000) Europejskie prawo wspólnotowe. Zagadnienia teorii i praktyki, Warszawa.

9. Niewęgłowski A. (2006), Controlling w jednostkach administracji publicznej, Zeszyty Naukowe Uniwersytetu Szczecińskiego, „Ekonomiczne problemy usług" nr 1.

10. Ochendowski E., (2002) Prawo administracyjne część ogólna, TNOiK Dom Organizatora, Torun.

11. Paczuła C., (1998) Kontrola wewnętrzna w zarzadzaniu jednostka gospodarcza, Difin, Warszawa.

12. Płoskonka J. (2006), Pojęcie kontroli w ujęciu zarządczym, „Kontrola Państwowa" nr 2.

13. Prawo administracyjne, J. Boć (red.), (2007) Kolonia Limited, Wrocław.

14. Siwoń M. (2006) Aplikacja międzynarodowych standardów wewnętrznej kontroli finansowej do polskiego systemu prawnego, Zeszyty Naukowe Uniwersytetu Szczecińskiego. „Ekonomiczne problemy usług”, nr 1.

15. Siwoń M. (2006), Pojęcia audytu i kontroli a działalność regionalnych izb obrachunkowych, "Finanse Komunalne” nr 1-2.

16. Ustawa z dnia 27 sierpnia 2009 roku o finansach publicznych, Dz. Ust. z 2009r. nr 157.

17. Wierzbowski M. (red.), (2009) Prawo administracyjne, Lexis Nexis, wyd. V.

18. Zimmermann J., (2008) Prawo administracyjne, Wolters Kluwer, wyd. 3, Warszawa.

19. Strona internetowa: www.sejm.gov.pl (19.01.12). 